\title{
IMPROVING THE QUALITY OF RELIGIOUS LEARNING DURING THE COVID-19 PANDEMIC THROUGH A REFLECTIVE MODEL FOR ISLAMIC RELIGIOUS EDUCATION TEACHERS
}

\author{
Ahmadi \\ Kementerian Agama Kabupaten Mojokerto \\ email: alabid.ahmad1@gmail.com
}

\begin{abstract}
This study aims to determine the level of effectiveness of the reflective model in improving the quality of learning during the COVID-19 pandemic. The results of this study provide a technical picture of policy making in education units as well as actions that need to be taken to improve the quality of Islamic Religious Education teachers in primary schools. This research shows that Islamic Religious Education teachers in schools have different views and learning styles in responding to the COVID-19 pandemic. As much as $87 \%$ of teachers agree with the Learning From Home (LFH) policy, but the rest think that learning will not be of good quality if it is done online. The interesting thing that was revealed in this study was that the teachers of Islamic Religious Education had optimism and enthusiasm to improve the quality of learning through various learning innovations in the midst of a pandemic. Revlective Model emphasizes learning that involves reflective thinking activities in the process. This study used an action research method involving 32 Islamic Religious Education teachers from 30 elementary schools in Mojokerto district. The process of planning, implementing, observing and evaluating is carried out with 2 models, namely synchronous and asynchronous.
\end{abstract}

Keywords: learning; COVID-19; reflective model; teacher; islamic religious education

\begin{abstract}
Abstrak: Penelitian ini bertujuan untuk mengetahui tingkat efektivitas model reflektif dalam meningkatkan kualitas pembelajaran di masa pandemi COVID-19. Hasil penelitian ini memberikan gambaran teknis pengambilan kebijakan di satuan pendidikan serta tindakan yang perlu dilakukan untuk meningkatkan kualitas guru Pendidikan Agama Islam di sekolah dasar. Penelitian ini menunjukkan bahwa guru Pendidikan Agama Islam di sekolah memiliki pandangan dan gaya belajar yang berbeda dalam menyikapi pandemi COVID-19. Sebanyak 87\% guru setuju dengan kebijakan Learning From Home (LFH), namun selebihnya berpendapat bahwa pembelajaran tidak akan berkualitas jika dilakukan secara online. Hal menarik yang terungkap dalam penelitian ini adalah para guru PAI memiliki optimisme dan semangat untuk meningkatkan kualitas pembelajaran melalui berbagai inovasi pembelajaran di tengah pandemi. Model Reflektif menekankan pada pembelajaran yang melibatkan kegiatan berpikir reflektif dalam prosesnya. Penelitian ini menggunakan metode penelitian tindakan yang melibatkan 32 guru Pendidikan Agama Islam dari 30 Sekolah Dasar di Kabupaten Mojokerto. Proses perencanaan, pelaksanaan, pengamatan dan evaluasi dilakukan dengan 2 model yaitu synchronous dan asynchronous.
\end{abstract}

Kata Kunci: belajar; COVID-19; model reflektif; guru; pendidikan agama islam 


\section{INTRODUCTION}

The increasing number of positive cases of COVID-19 in Indonesia including the number of people from the age group of children and adolescents encourages some parties to continue to support the policy of closing schools and other learning institutions (Setiati \& Azwar, 2020). Judging from the educational aspect, the application of online learning during school closures is considered not to be an appropriate and viable alternative to Islamic religious education due to the characteristic factors of learning and also inadequate resource support (Muazza et al., 2018). In following elementary school level learning, especially those in the area experienced many obstacles in the learning process. This condition requires teachers to increase creativity and innovation in carrying out teaching and learning activities. Teachers at this level are not only asked to continue to provide learning so as not to experience lags, but also as a very responsible party in creating an interesting learning atmosphere, spirit of learning and knowledge transfer (Djaswadi, 2021; Hanafi et al., 2020; Mahmudah, 2021).

More severe conditions may be felt by Islamic Religious Education teachers at the elementary school level. They have a responsibility that is not light. Class mastery in carrying out learning activities is not only to convey theory but also to convey the practice of iibadah activities. Students need a coordination of body movement learning in learning such as prayer worship learning. Recite the Qur'an and religious books are required to come face to face so that teachers know the quality of reading, makhraj, and eloquence, as well as the quality of understanding and understanding of religious books. Another reason, religious education is character building education that must be monitored continuously over a long period of time (Ahmad et al., 2020; White et al., 2021).

Government decisions related to learning activities change rapidly over time. The last policy is in accordance with the joint decision of the Minister of Education and Culture, Minister of Religious Affairs, Minister of Health and Minister of Home Affairs of the Republic of Indonesia decided that education is still not allowed to conduct face-to-face education activities. This condition makes some islamic education teachers need to improve their skills, especially in the field of information technology. The data collected by researchers shows that class 
management capabilities during the COVID-19 pandemic are relatively low. This is evidenced by field observation and academic supervision conducted by researchers. Academic supervision is emphasized on 3 main component aspects, namely learning planning, learning process and implementation and learning evaluation. These three components greatly affect the quality of learning (Mugiyono, 2021)

The decrease in the quality of learning that occurs at the elementary school level, especially islamic education subjects, makes some researchers think that the main factor that causes it is innovation of low religious learning and tends to be monotonous (Sutisna \& Indraswati, 2021; Syamsidah et al., 2021). Learning innovation plays an important role in the press of teaching and learning activities (Rofik, 2019, 2019). The characteristics of elementary school students that are different from other levels of education require the intervention of many parties in solving this problem. This study aims to find out more clearly the quality of learning of Islamic Religious Education teachers in elementary schools in the midst of the COVID-19 outbreak. This research also reveals efforts to improve the quality of learning by using reflective learning models that have been proven to provide good academic supervision actions.

Reflective Model is one of the efforts of education supervisors in providing guidance and evaluation of activities and learning processes conducted by teachers in schools. Reflective learning model emphasizes classroom mastery, preparation of learning tools, process of teaching and learning activities to evaluation of learning. Reflective model has at least been done by researchers to improve the quality of learning in various countries (Farahian et al., 2021; Gayathri et al., 2021, 2021; Rădulescu, 2013). Researchers try to provide reflective model actions in three ways, namely academic mentoring, improvement of online learning skills and evaluation of learning for Islamic Religious Education teachers in elementary school level.

This research is very important to do considering that not many researchers focus on solving field problems with methods of action in research at the elementary education level. This research also reveals a gap between conventional learning and online learning that is enforced today considering the pandemic is still ongoing. 
Although data shows that the rate of COVID-19 infection in children and adolescents is relatively low (Ludvigsson, 2020). In addition, the effectiveness of Religious learning in elementary schools also becomes controlled by the presence of education supervisors. Hopefully this research can be a source of inspiration for government policy making, especially the Education Office in carrying out academic supervision to improve the quality of learning in Indonesia.

\section{METHOD}

This research is qualitative research with the approach of Surveillance Action Research conducted by school supervisors as researchers. The subjects of this study were 32 Islamic Religious Education teachers from 30 elementary schools in Trowulan and Pungging in Mojokerto, East Java. The research was conducted in 3 cycles covering planning, action, observation and reflection from January to March 2021.

Figure 1. Surveillance Action Research Flow Plans

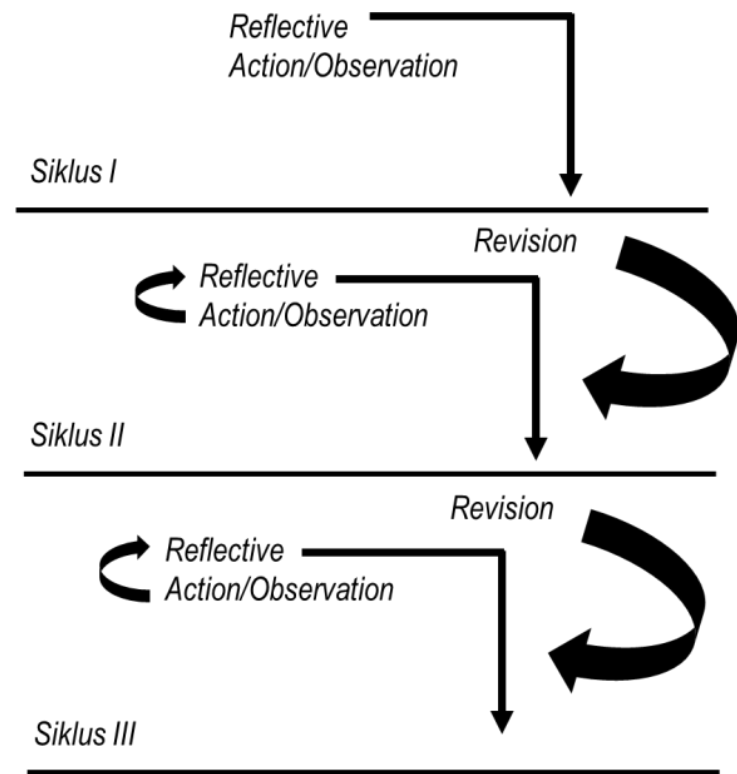

Revision

This study was conducted with 2 models, namely synchronous and asynchronous. Aims to avoid direct contact with research subjects as it was implemented during the COVID-19 pandemic. The research also used various 
communication media zoom meeting, google meet, whatsapp and limited field observation. The first stage, this research is a planning phase that is interpreted as an action plan to improve, improve or change behaviors and attitudes as a solution in learning practices. In this case is the improvement of the quality of religious learning. The next phase of action, namely efforts to improve, improve or change desired by researchers. Observation that is observing the results or impact of actions carried out on teachers is the next activity. Then the reflection phase is done to review, see, and consider the results or impacts of actions of various criteria. The revision as the last phase is carried out based on the results of reflections that have been done.

This surveillance action research confirms that the variable studied is the improvement of the quality of religious learning during the COVID-19 pandemic through reflective methods for Islamic Religious Education teachers in Mojokerto district. The indicator of achievement of this study is when $85 \%$ of teachers from the schools studied have achieved a minimum completion with a score of 75 . If the increase has occurred in cycles 1 and 2, then the next cycle does not need to be done because The Action has been judged effective. This is based on some research that has been done before (Mugiyono, 2021; Wardani et al., 2021)

Data analysis techniques are used to calculate the magnitude of the improvement in learning quality using percentage techniques. Quantitative data obtained from the results of pretest and posttest which is then conducted different test analysis with t test and ANOVA. Field confirmation is also done by assessing the learning tools that have been made by each islamic education teacher. Assessment of learning devices, implementation of learning and evaluation of learning is carried out using the 2013 Curriculum standard issued by the Ministry of Education and Culture of the Republic of Indonesia.

\section{RESULT AND DISCUSSION}

This research found a new paradigm in the study of Islam in elementary school. These findings are based on 3 important aspects namely teacher professionalism, self-development and effective communication. These three components are obtained from the results of an in-depth study of Islamic Religious 
Education teachers during the COVID-19 pandemic. The COVID-19 pandemic requires teachers to innovate learning, especially in the field of information and communication technology mastery (Djaswadi, 2021; Saefi et al., 2020; Ulhaq et al., 2020). On the other hand, this condition has a positive impact in the form of improving the ability of teachers to adapt quickly according to the needs of the times (Mahmudah, 2021; Xue et al., 2021).

Primary School level is one of the most important education sectors to consider. At this age, children have different characteristics than high school-age students or college students. Teachers are required to be more active in providing understanding especially during the COVID-19 pandemic. It is not easy for teachers to carry out distance learning with uneven facilities in various regions. This condition makes teachers have to innovate learning in order to be able to attract the attention of children in learning the subjects taught (Kusumaningtyas et al., 2020; Syamsidah et al., 2021).

Islamic Religious Education has special characteristics in carrying out learning at the elementary school level. Teachers are not only required to transfer religious knowledge, but also provide certain worship practices that must be taught such as prayer readings, reading the Quran, daily prayers and various other PAI learnings. This research at least provides an overview of the process and efforts to improve the quality of learning of Islamic Religious Education teachers in elementary schools. The following is a table of sociodemographic characteristics of research respondents.

Table 1. School Distribution Profile

\begin{tabular}{|c|c|c|c|c|c|c|}
\hline No. & Responden & Male & Female & PNS & $\begin{array}{l}\text { Non- } \\
\text { PNS }\end{array}$ & Student \\
\hline 1. & SD Negeri Jambuwok & & 1 & 1 & & 204 \\
\hline 2. & SD Negeri Domas & 1 & & & 1 & 92 \\
\hline 3. & SD Negeri Beloh & 1 & & 1 & & 256 \\
\hline 4. & SD Negeri Temon & & 1 & & 1 & 233 \\
\hline 5. & SD Negeri Pakis 1 & 1 & & & 1 & 187 \\
\hline 6. & SD Negeri Pakis 2 & & 1 & & 1 & 125 \\
\hline 7. & SD Negeri Sentonorejo & 1 & & & 1 & 227 \\
\hline 8. & SD Negeri Trowulan & & 1 & 1 & & 374 \\
\hline 9. & SD Negeri Bejijong 1 & 1 & & 1 & & 177 \\
\hline 10. & SD Negeri Bejijong 2 & 1 & & & 1 & 116 \\
\hline 11. & SD Negeri Kejagan & 1 & & 1 & & 199 \\
\hline 12. & SD Negeri Jatipasar & 1 & & 1 & & 151 \\
\hline 13. & SD Negeri Watesumpak 1 & 1 & & & 1 & 168 \\
\hline 14. & SD Negeri Watesumpak 2 & & 1 & & 1 & 169 \\
\hline
\end{tabular}


15. SD Negeri Wonorejo 1

16. SD Negeri Wonorejo 2

17. SD Negeri Panggih

18. SD Negeri Bicak

19. SD Negeri Balongwono

20. SD Negeri Pungging 1

21. SD Negeri Pungging 2

22. SD Negeri Pungging 3

23. SD Negeri Lebaksono

24. SD Negeri Tunggalpager

25. SD Negeri Balongmasin 1

26. SD Negeri Balongmasin 2

27. SD Negeri Jabon

28. SD Negeri Kedungmungal

29. SD Islam Nahrul Ulum

30. SD Islam Elkisi Total
1

1

1

1

1

1

1

1

1

1

1

1

1

1

17

Table 2. Sosiodemographic Characteristics of the Partisipans ( $n=32$ )

\begin{tabular}{clccc}
\hline No. & & \multicolumn{2}{c}{ Responden } \\
\cline { 3 - 4 } & & Freq $(\boldsymbol{n})$ & \% \\
\hline $\mathbf{1}$ & Gender & 17 & 53.1250 \\
& Male & 15 & 46.8750 \\
& Famale & & \\
$\mathbf{2}$ & Age & 18 & 56.2533 \\
& $<30$ & 14 & 43.7530 \\
& $>30$ & & \\
$\mathbf{3}$ & Status & 13 & 40.62512 \\
& PNS & 19 & 59.37522 \\
& Non-PNS & & & \\
$\mathbf{4}$ & Majors of Education & 26 & 81.2533 \\
& Islamic Education & 6 & 18.7533 \\
\hline
\end{tabular}

The demographic distribution of these respondents influences the effectiveness of the given action. Efforts to improve the quality of learning during the COVID-19 pandemic for Islamic Religious Education teachers at the elementary school level are divided into 3 cycles of action. The activity in cycle I is to carry out guidance in the form of academic supervision. Supervision is an assessment and mentoring activity of teacher competence in carrying out teaching and learning activities. This activity aims to provide evaluation and disability improvement to teachers and solve problems that occur in the learning process. Academic supervision is emphasized on the preparation of learning device documents in accordance with national standards that have been determined. In cycle I, pretest activities are carried out followed by the exposure of materials to 
support religious learning through online, followed by discussions and ended with posttest. Here is a spread of observations of teacher activity in cycle I that focuses on exploring the quality of learning tools, the achievement of tasks, and the implementation of online learning during the pandemic.

Tabel 3. Result of Cycle I

\begin{tabular}{|c|c|c|c|c|c|}
\hline No. & Responden & Pretest & $\begin{array}{l}\text { Learning } \\
\text { Plan (LP) }\end{array}$ & $\begin{array}{l}\text { Learning \& } \\
\text { Teaching } \\
\text { (LT) }\end{array}$ & $\begin{array}{l}\text { Assesment } \\
\text { (AS) }\end{array}$ \\
\hline \multirow[t]{3}{*}{1} & Gender & & & & \\
\hline & Male & 67.75 & 70.33 & 72.15 & 64.66 \\
\hline & Female & 73.86 & 73.48 & 70.65 & 68.90 \\
\hline \multirow[t]{3}{*}{2} & Age & & & & \\
\hline & $<30$ & 76.33 & 74.63 & 75.05 & 70.00 \\
\hline & $>30$ & 64.25 & 70.18 & 70.65 & 68.90 \\
\hline \multirow[t]{3}{*}{3} & Status & & & & \\
\hline & PNS & 68.66 & 74.75 & 70.90 & 69.00 \\
\hline & Non-PNS & 70.63 & 69.85 & 71.45 & 63.00 \\
\hline \multirow[t]{4}{*}{4} & Major of Education & & & & \\
\hline & Islamic Education & 72.45 & 73.66 & 74.00 & 71.00 \\
\hline & Non-Islamic & 68.95 & 70.80 & 72.30 & 68.00 \\
\hline & Education & & & & \\
\hline
\end{tabular}

The data above are grouped into 4 categories, namely gender, age, staffing status and academic qualifications. These results show that the level of ability of teachers in planning learning is still relatively low. Even for teachers of Islamic Religious Education non-civil servants only get a score of 69.85 which means the ability of teachers is still in a low position. This correlates with the assessment of supervisors when the implementation of learning. An average score of 73.56 indicates that teachers need to improve their educational skills. This is because the measurement instruments used are based on the reference of the learning standards of the "Merdeka Belajar" program initiated by the government in line with the COVID-19 outbreak. Indirectly this greatly affects the teacher's psychological where they have to change the style of face-to-face learning that is usually done in the classroom, switching to virtual classes through online media.

Research in cycle I also found the fact that Islamic Religious Education teachers still have difficulty in conducting learning evaluation activities. This is due to the difference in the learning system conducted by each school. The government 
based on the Decree of the Minister of Education and Culture of the Republic of Indonesia Number 1 of 2020 confirms that learning is conducted online by not imposing the completion of the curriculum as it should be. Teachers are given the freedom to manage classes and carry out learning using various media and learning innovations in an "Merdeka" manner in accordance with central government policy.

The pretest results conducted by researchers before conducting research actions, related to the knowledge, attitudes and practices of teachers in carrying out learning during the COVID-19 pandemic. From the data above it can be known that the average pretest value still tends to be low. This condition is influenced by several factors including age and gender. This study showed that female Islamic Education teachers had higher pretest scores than men at 73.86 with 67.75 and teachers under the age of 30 had better knowledge, attitudes and learning practices than teachers over the age range of more than 30 years. This condition is consistent with Hanafi's research which says that age will affect the level of effective communication of teachers with students (Hanafi et al., 2020). This will certainly affect the ability of teachers in carrying out online learning.

Teacher skills are a prerequisite for learning success (Djaswadi, 2021). Teachers are required to have good academic ability in organizing learning. Transfer of knowledge from teacher to student requires not only accuracy of knowledge but also has good classroom management skills (Kusumaningtyas et al., 2020; Mahmudah, 2021; Syamsidah et al., 2021). The higher the quality of learning conducted by teachers, the better the learning outcomes that will be obtained by students (Fernández-Peña et al., 2016). This is the basis of the importance of research on this surveillance action carried out. To achieve comprehensive research results, this research was conducted in 2 cycles with reflective model approach. Reflective learning model is a reflective learning technique that is based on improving the results of academic supervision that has been done by the education supervisor. Reflective defense is a learning process that involves reflective thinking activities in the process (Farahian et al., 2021; Gurzynski-Weiss, 2014).

Based on the results of the study in cycle I obtained the results that the ability of Islamic Religious Education teachers in learning is still relatively low, the researchers took action in the form of coaching the improvement of learning skills 
and quality by using reflective learning models. This learning model emphasizes that teachers as research subjects play an active role in following academic guidance. Improving the quality of learning is emphasized in 3 aspects, namely learning planning, implementation of online learning and evaluation of online shopping. Reflective model used in this study refers to ignatian pedagogy paradigm consisting of 3 main elements namely experience, reflection and action (Kolvenbach, 2021).

Figure 2. Reflective Learning Model

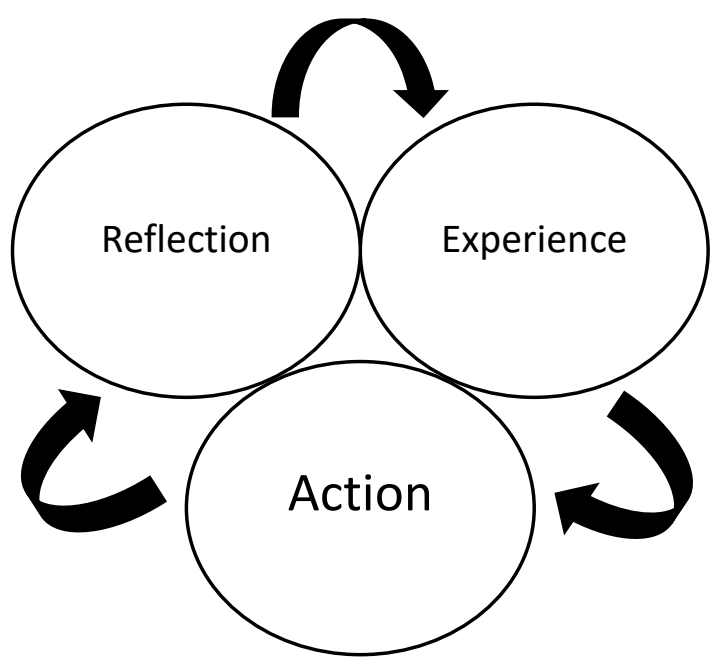

Reflective model has had a significant impact on teachers' ability to improve the quality of religious learning during the COVID-19 pandemic. This is indicated by cycle II data that shows the following results.

Table 4. Result of Cycle II

\begin{tabular}{|c|c|c|c|c|c|c|}
\hline No. & Responden & Pretest & $\begin{array}{l}\text { Learning } \\
\text { Plan (LP) }\end{array}$ & $\begin{array}{l}\text { Learning \& } \\
\text { Teaching } \\
\text { (LT) }\end{array}$ & $\begin{array}{c}\text { Assesment } \\
\text { (AS) }\end{array}$ & Posttest \\
\hline \multirow[t]{3}{*}{1} & Gender & & & & & \\
\hline & Male & 77.80 & 96.00 & 90.10 & 83.60 & 93.12 \\
\hline & Female & 79.80 & 97.80 & 93.60 & 84.50 & 93.90 \\
\hline \multirow[t]{3}{*}{2} & Age & & & & & \\
\hline & $<30$ & 79.33 & 95.60 & 95.00 & 91.50 & 89.95 \\
\hline & $>30$ & 78.55 & 93.50 & 93.60 & 90.50 & 90.40 \\
\hline \multirow[t]{3}{*}{3} & Status & & & & & \\
\hline & PNS & 78.77 & 95.70 & 93.90 & 89.70 & 93.60 \\
\hline & Non-PNS & 79.63 & 96.80 & 94.40 & 90.80 & 94.50 \\
\hline \multirow[t]{3}{*}{4} & $\begin{array}{l}\text { Major of } \\
\text { Education }\end{array}$ & & & & & \\
\hline & Islamic Education & 79.75 & 96.60 & 93.00 & 87.60 & 95.60 \\
\hline & $\begin{array}{l}\text { Non-Islamic } \\
\text { Education }\end{array}$ & 77.95 & 94.80 & 95.30 & 90.50 & 95.05 \\
\hline
\end{tabular}


It is interesting to note that the improvement of the quality of religious learning by teachers occurs because of several things, namely the provision of actions in the form of training and mentoring the creation of learning plans and facilitation of online learning through google meet. This shows that the quality of learning is not only determined by school facilities and infrastructure, but also determined by the competence of teachers in line with some previous research (Gayathri et al., 2021; Rahman Talukder et al., 2021; Yusuf \& Wekke, 2015).

Table 5. Gender-based test

\begin{tabular}{lllrrr}
\hline & Gender & N & Mean & $\begin{array}{c}\text { Std. } \\
\text { Deviation }\end{array}$ & $\begin{array}{c}\text { Std. Error } \\
\text { Mean }\end{array}$ \\
\hline Learning Plan & Male & 17 & 86.0493 & 9.42755 & .66168 \\
(LP) & Female & 15 & 82.0711 & 9.38437 & .66861 \\
Learning \& & Male & 17 & 60.9360 & 7.04939 & .49477 \\
Teaching (LT) & Female & 15 & 58.3503 & 6.80217 & .48463 \\
Assessment (AS) & Male & 17 & 64.6502 & 6.70162 & .47036 \\
& Female & 15 & 62.7360 & 6.66099 & .47458 \\
Total & Male & 17 & 211.6355 & 18.83133 & 1.32170 \\
& Female & 15 & 203.1574 & 19.22293 & 1.36958 \\
\hline
\end{tabular}

Table 6 . T-test results by gender

\begin{tabular}{|c|c|c|c|c|c|c|c|c|}
\hline & & F & Sig. & $\mathbf{T}$ & df & $\begin{array}{c}\text { Sig. } \\
(2- \\
\text { tailed } \\
)\end{array}$ & $\begin{array}{c}\text { Mean } \\
\text { Differe } \\
\text { nce }\end{array}$ & $\begin{array}{c}\text { Std. } \\
\text { Error } \\
\text { Differe } \\
\text { nce }\end{array}$ \\
\hline \multirow[t]{2}{*}{ LP } & $\begin{array}{l}\text { Equal var } \\
\text { assumed }\end{array}$ & .001 & .970 & 4.229 & 398 & .000 & 3.97820 & .94074 \\
\hline & $\begin{array}{l}\text { Equal var not } \\
\text { assumed }\end{array}$ & & & 4.229 & 397.742 & .000 & 3.97820 & 94067 \\
\hline \multirow[t]{2}{*}{ LT } & $\begin{array}{l}\text { Equal var } \\
\text { assumed }\end{array}$ & .075 & .784 & 3.731 & 398 & .000 & 2.58571 & 69295 \\
\hline & $\begin{array}{l}\text { Equal var not } \\
\text { assumed }\end{array}$ & & & 3.733 & 397.987 & .000 & 2.58571 & .69258 \\
\hline \multirow[t]{2}{*}{ AS } & $\begin{array}{l}\text { Equal var } \\
\text { assumed }\end{array}$ & .000 & .982 & 2.865 & 398 & .004 & 1.91421 & .66824 \\
\hline & $\begin{array}{l}\text { Equal var not } \\
\text { assumed }\end{array}$ & & & 2.865 & 397.771 & .004 & 1.91421 & 66818 \\
\hline \multirow[t]{2}{*}{$\begin{array}{l}\text { Tot } \\
\text { al }\end{array}$} & $\begin{array}{l}\text { Equal var } \\
\text { assumed }\end{array}$ & .136 & .712 & 4.456 & 398 & .000 & 8.47811 & 1.90273 \\
\hline & $\begin{array}{l}\text { Equal var not } \\
\text { assumed }\end{array}$ & & & 4.454 & 396.982 & .000 & 8.47811 & 1.90332 \\
\hline
\end{tabular}

Based on the test results using non-paired t test obtained sig value. $\mathrm{p}$ for knowledge 0.000 , attitude 0.000 , skills 0.004 , and a total of 0.000 , then for the components of learning plan, learning \&teaching, assessment and the number there is a real difference between men and women, where men are better. reviewed from 
learning plan, learning \& teaching, assessment and quantity, assuming the value of $p<0.05$ then can be expressed differently. Even in these results, all $p$ values are less than 0.01 , which means at a better level of significance, with a confidence level of 99\%. From the data above it can be concluded that the implementation of cycle II has shown excellent results. Thus, cycle III in the study of this surveillance action is not necessary to be implemented.

\section{CONCLUSION}

This research has shown that the improvement of the quality of religious learning during the COVID-19 pandemic for Islamic Religious Education teachers at the elementary school level can be measured by 3 things, namely learning plan, learning \&teaching, and assessment. These three components should be given action by the Education supervisor to provide academic guidance and supervision on the learning conducted. This study confirms the correlation between the readiness of learning devices and the implementation of learning. The better the process of preparing learning tools, the better the quality of learning implementation. Islamic Religious Education Teachers have a high level of media adaptation and learning innovation during the COVID-19 pandemic. The paradigm change of online learning that began to be introduced with the concept of "Merdeka Belajar" also requires teachers to continue to develop in accordance with the conditions of the times.

\section{ACKNOWLADGMENT}

We would like to thank the Affair of the Ministry of Religion of Mojokerto for facilitating this research and to elementary schools and madrasah ibtidaiyah in the Trowulan and Pungging districts for their willingness to support this research activity.

\section{REFERENCES}

Ahmad, I. F., Putro, N. H. P. S., Thontowi, Z. S., Syafii, A., \& Subakti, M. A. (2020). Trends in the Implementation of Higher-Order Thinking Skills in Islamic Religious Education in Madrasahs and Schools: A Systematic Literature Review. Jurnal Pendidikan Islam, 9(2), 195-216. https://doi.org/10.14421/jpi.2020.92.195-216 
Djaswadi, D. (2021). Upaya Peningkatan Kompetensi Guru Dalam Menerapkan Pembelajaran Daring Masa Pandemi Covid 19 Dapat Meningkatkan Prestasi Belajar Peserta Didik SD Negeri Tambahagung 03 Kecamatan Tambakromo Semester I Tahun Ajaran 2020/2021. Journal of Industrial Engineering \& Management Research, 2(1), 156-179. https://doi.org/10.7777/jiemar.v2i1.122

Farahian, M., Avarzamani, F., \& Rajabi, Y. (2021). Reflective thinking in an EFL Writing course: To what level do portfolios improve reflection in writing?

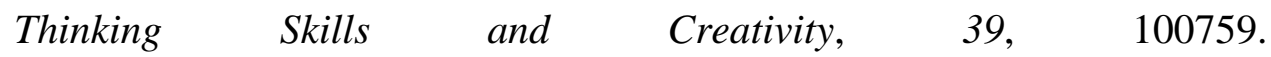
https://doi.org/10.1016/j.tsc.2020.100759

Fernández-Peña, R., Fuentes-Pumarola, C., Malagón-Aguilera, M. C., BonmatíTomàs, A., Bosch-Farré, C., \& Ballester-Ferrando, D. (2016). The evaluation of reflective learning from the nursing student's point of view: A mixed method approach. Nurse Education Today, 44, 59-65. https://doi.org/10.1016/j.nedt.2016.05.005

Gayathri, B., Vedavyas, R., Sharanya, P., \& Karthik, K. (2021). Effectiveness of reflective learning in skill-based teaching among postgraduate anesthesia students: An outcome-based study using video annotation tool. Medical Journal Armed Forces India, 77, S202-S207. https://doi.org/10.1016/j.mjafi.2020.12.028

Gurzynski-Weiss, L. (2014). Triangulating Graduate Instructor Learning in FL Teaching Methods: Questionnaires, Concept Maps, and Reflective Teaching Journals. Procedia - Social and Behavioral Sciences, 141, 171181. https://doi.org/10.1016/j.sbspro.2014.05.031

Hanafi, Y., Murtadho, N., Hassan, A. R., Ikhsan, M. A., \& Diyana, T. N. (2020). Development and validation of a questionnaire for teacher effective communication in Qur'an learning. British Journal of Religious Education, 42(4), 424-434. https://doi.org/10.1080/01416200.2019.1705761 
Kolvenbach, F. (2021). Ignatian Pedagogy: A Practical Approach 1993. Educate Magis. https://www.educatemagis.org/living-tradition/ignatian-pedagogya-practical-approach/

Kusumaningtyas, R., Sholehah, I. M., \& Kholifah, N. (2020). Peningkatan Kualitas Pembelajaran Guru Melalui Model dan Media Pembelajaran bagi Generasi Z. Warta LPM, 23(1), 54-62. https://doi.org/10.23917/warta.v23i1.9106

Ludvigsson, J. F. (2020). Systematic review of COVID-19 in children shows milder cases and a better prognosis than adults. Acta Paediatrica, 109(6), 10881095. https://doi.org/10.1111/apa.15270

Mahmudah, S. (2021). Peningkatan Kualitas Pembelajaran Guru Kelas V dan VI melalui Pembimbingan Partisipasi Aktif Kepala Sekolah di SD Negeri 2 Jobokuto Jepara Tahun Pelajaran 2019/2020. JURNAL PENDIDIKAN, 30(1), 105-112. https://doi.org/10.32585/jp.v30i1.1244

Muazza, M., Mukminin, A., Habibi, A., \& Hidayat, M. (2018). Education in Indonesian Islamic Boarding Schools: Voices on Curriculum and Radicalism, Teacher, and Facilities. The Islamic Quarterly, 62(4), 507-536.

Mugiyono, M. (2021). Supervisi Kepala Sekolah Terhadap Kinerja Guru SD Negeri 219 Bengkulu Utara Untuk Meningkatkan Kualitas Pembelajaran. JPT: Jurnal Pendidikan Tematik, 2(1), 1-12.

Rădulescu, C. (2013). Reinventing Reflective Learning Methods in Teacher Education. Procedia - Social and Behavioral Sciences, 78, 11-15. https://doi.org/10.1016/j.sbspro.2013.04.241

Rahman Talukder, Md. M., Green, C., \& Mamun-ur-Rashid, Md. (2021). Primary science teaching in Bangladesh: A critical analysis of the role of the DPEd program to improve the quality of learning in science teaching. Heliyon, 7(2), e06050. https://doi.org/10.1016/j.heliyon.2021.e06050 
Rofik. (2019). Development of Islamic Cultural History Learning Materials in Indonesia's 2013 Curriculum. Jurnal Pendidikan Islam, 8(2), 309-344. https://doi.org/10.14421/jpi.2019.82.309-344

Saefi, M., Fauzi, A., Kristiana, E., Adi, W. C., Muchson, M., Setiawan, M. E., Islami, N. N., Ningrum, D. E. A. F., Ikhsan, M. A., \& Ramadhani, M. (2020). Survey data of COVID-19-related knowledge, attitude, and practices among indonesian undergraduate students. Data in Brief, 31, 105855. https://doi.org/10.1016/j.dib.2020.105855

Setiati, S., \& Azwar, M. K. (2020). COVID-19 and Indonesia. Acta Medica Indonesiana, 51(1), 84-89.

Sutisna, D., \& Indraswati, D. (2021). KECAKAPAN MANAJEMEN KELAS GURU SEBAGAI UPAYA PENYELESAIAN PROBLEMATIKA PEMBELAJARAN DIMASA PANDEMI COVID 19. Pendas : Jurnal Ilmiah Pendidikan Dasar, 5(2), 204-220. https://doi.org/10.23969/jp.v5i2.3491

Syamsidah, S., T, R., Qurani, B., \& Muhiddin, A. (2021). Peningkatan Kualitas Profesionalisme Guru dengan Pelatihan Model Model Pembelajaran. Seminar Nasional Pengabdian Kepada Masyarakat, O(0), Article 0. https://ojs.unm.ac.id/semnaslpm/article/view/18287

Ulhaq, Z. S., Kristanti, R. A., Hidayatullah, A. A., Rachma, L. N., Susanti, N., \& Aulanni'am, A. (2020). Data on attitudes, religious perspectives, and practices towards COVID-19 among Indonesian residents: A quick online cross-sectional survey. Data in Brief, 32, 106277. https://doi.org/10.1016/j.dib.2020.106277

Wardani, R. K., Santosa, H., \& Rahmawati, D. (2021). The Role of Academic Supervision and Communication on Teacher Performance. Journal of Education Research and Evaluation, 5(2), Article 2. https://doi.org/10.23887/jere.v5i2.31597 
White, C. J., Baimel, A., \& Norenzayan, A. (2021). How cultural learning and cognitive biases shape religious beliefs. Current Opinion in Psychology, 40, 34-39. https://doi.org/10.1016/j.copsyc.2020.07.033

Xue, Q., Xie, X., Liu, Q., Zhou, Y., Zhu, K., Wu, H., Wan, Z., Feng, Y., Meng, H., Zhang, J., Zuo, P., \& Song, R. (2021). Knowledge, attitudes, and practices towards COVID-19 among primary school students in Hubei Province, China. Children and Youth Services Review, 120, 105735. https://doi.org/10.1016/j.childyouth.2020.105735

Yusuf, M., \& Wekke, I. S. (2015). Active Learning on Teaching Arabic for Special Purpose in Indonesian Pesantren. Procedia - Social and Behavioral Sciences, 191, 137-141. https://doi.org/10.1016/j.sbspro.2015.04.245 